\title{
Obesity Does not Compromise Ovarian Reserve Markers in Infertile Women
}

\author{
Übergewicht führt zu keiner Beeinträchtigung \\ der ovariellen Reserve bei unfruchtbaren Frauen
}

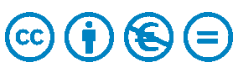

\author{
Authors \\ Umit Gorkem ${ }^{1}$, Ferit Kerim Kucukler ${ }^{2}$, Cihan Togrul ${ }^{1}$, Şebnem Gulen ${ }^{3}$
}

Affiliations

1 Hitit University Faculty of Medicine, Department of Obstetrics and Gynecology, Corum, Turkey

2 Hitit University Faculty of Medicine, Department of Endocrinology, Corum Turkey

3 Ufuk University Faculty of Medicine, Department of Physiology, Ankara, Turkey

Key words

obesity, body mass index, waist circumference, ovarian reserve

Schlüsselwörter

Übergewicht, Body-Mass-Index, Taillenumfang, ovarielle Reserve

received 14.1.2018

revised 26.6.2018

accepted 28.6.2018

\section{Bibliography}

DOI https://doi.org/10.1055/a-0650-4723

Geburtsh Frauenheilk 2019; 79: 79-85 @ Georg Thieme

Verlag KG Stuttgart · New York | ISSN 0016-5751

Correspondence

Umit Gorkem

Hitit Universitesi Erol Olçok Eğitim ve Araştırma Hastanesi

Kadın Hastalıkları ve Doğum Kliniği IVF Bölümü Çorum

Inonu Cad., 19030 Çorum, Turkey

drumitgorkem@hotmail.com

\section{ABSTRACT}

Introduction In the literature, conflicting results from studies examining the relationship between obesity and ovarian reserve have been reported. The purpose of the study is to investigate whether obesity adversely affects serum concentrations of ovarian reserve markers in infertile women with different ovarian reserve status.
Materials and Methods A total of 402 women were assigned to three groups according to body mass index (BMI; $<25 \mathrm{~kg} / \mathrm{m}^{2}$ : normal, $\mathrm{n}=198 ; 25.0-29.9 \mathrm{~kg} / \mathrm{m}^{2}$ : overweight, $\mathrm{n}=126$; and $\geq 30 \mathrm{~kg} / \mathrm{m}^{2}$ : obese, $\mathrm{n}=78$ ). The women were also divided into two groups according to waist circumference (WC; < $80 \mathrm{~cm}$ : normal, $\mathrm{n}=103$; and $\geq 80 \mathrm{~cm}$ : obese, $\mathrm{n}=299$ ). Participants were also categorized into three types of ovarian reserve patterns: normal $(n=146)$, high $(n=112)$, and poor ovarian reserve $(n=144)$. The serum anti-Mullerian hormone $(\mathrm{AMH})$, estradiol (E2), and follicle-stimulating hormone (FSH) levels were assayed and compared in all groups.

Results There were no significant differences in BMI and WC in the three ovarian reserve groups. There were significant differences between all ovarian reserve groups for $\mathrm{AMH}, \mathrm{E} 2$, and FSH ( $p<0.001$ for all). The comparisons of ovarian reserve parameters (AMH, E2, and FSH) and obesity parameters (BMI and WC) revealed no significant differences in women with all ovarian reserve patterns.

Conclusion The parameters of ovarian reserve do not seem to be affected by increased BMI and WC. Thus, AMH may be considered as a reliable marker of ovarian reserve.

\section{ZUSAMMENFASSUNG}

Einleitung In der Literatur werden aus Studien, welche die Beziehung zwischen Übergewicht und ovarieller Reserve untersuchten, widersprüchliche Ergebnisse gemeldet. Ziel dieser Studie war es, zu untersuchen, ob Übergewicht negative Auswirkungen auf Konzentrationen von Markern von ovarieller Reserve im Blut bei unfruchtbaren Frauen mit unterschiedlicher ovarieller Reserve hat.

Material und Methoden Insgesamt wurden 402 Frauen in die Studie aufgenommen und gemäß ihrem Body-Mass-Index in 3 verschiedene Gruppen eingeteilt (BMI; $<25 \mathrm{~kg} / \mathrm{m}^{2}$ : normal, $\quad n=198 ; \quad 25.0-29.9 \mathrm{~kg} / \mathrm{m}^{2}$ : übergewichtig, $\mathrm{n}=126$; $\geq 30 \mathrm{~kg} / \mathrm{m}^{2}$ : adipös, $\mathrm{n}=78$ ). Die Frauen wurden auch gemäß ihrem Taillenumfang in 2 Gruppen eingeteilt (TU; <80 cm: normal, $n=103$; sowie $\geq 80 \mathrm{~cm}$ : adipös, $n=299$ ). Die Teilnehmerinnen wurden auch nach ihrer ovariellen Reserve in eine von 3 Kategorien eingeteilt: normale $(n=146)$, hohe $(n=112)$ und mangelhafte ovarielle Reserve $(n=144)$. Der Anti-Müller- 
Hormon-(AMH-)Spiegel, die Serum-Estradiol-(E2)-Werte und die FSH-Werte (FSH: follikelstimulierendes Hormon) wurden bei allen Gruppen untersucht und verglichen.

Ergebnisse Es gab keine signifikanten Unterschiede bezüglich BMI und TU zwischen den 3 Gruppen mit unterschiedlicher ovarieller Reserve. Es gab signifikante Unterschiede zwischen allen 3 Gruppen mit unterschiedlicher ovarieller Reserve bezüglich der AMH-, E2- und FSH-Werte $(p<0,001$ für alle). Ein Vergleich der Parameter für die ovarielle Reserve (AMH, E2 und FSH) und der Adipositasparameter (BMI und TU) zeigte keine signifikanten Unterschiede zwischen Frauen mit unterschiedlicher ovariellen Reserve.

Schlussfolgerung Es scheint, dass die Parameter der ovariellen Reserve nicht durch einen höheren BMI oder einen weiten Taillenumfang beeinflusst werden. AMH darf daher als zuverlässiger Marker für die ovarielle Reserve betrachtet werden.

\section{Introduction}

As simple definitions, obesity is an excess storage of triglycerides in adipose tissues and overweight is having a body weight, including muscles, fat, and body water, in excess of a standard or ideal body weight [1]. According to the World Health Organization (WHO), the term overweight has been defined as having a body mass index (BMI) equal to or greater than $25 \mathrm{~kg} / \mathrm{m}^{2}$, while obesity is having a BMI equal to or greater than $30 \mathrm{~kg} / \mathrm{m}^{2}$ [2]. The BMI is a practical and globally-used measure of obesity. However, it does not consider the person's degree of abdominal obesity [3]. On the other hand, waist circumference (WC) is an easy and reliable measure of visceral adipose tissue and can be used as a simple index of cardiovascular risk [4]. The WHO has reported sex-specific cutoff values that define overweight and obesity [3]. With regard to abdominal obesity, the WC cutoff value specific to the population of Turkish women is $\geq 80 \mathrm{~cm}$ estimated as $80 \mathrm{~cm}$ [5].

Obesity has emerged as a global epidemic. The International Obesity Task Force reported that 1.1 billion adults are overweight, and 312 million of these are women who are considered obese [6]. The WHO has reported that $60 \%$ of women are overweight in the United States and most European countries, and 30\% of these women are considered obese [2,6]. The prevalence of obesity has reached more than one third of the adult population in Turkey, similar to most of the worldwide populations [7, 8].

Obesity is associated with numerous personal characteristics including social, psychological, and demographical issues, and health problems. Moreover, being obese has a detrimental impact on most organ systems, including the reproductive system. Although the mechanisms are complex and multifactorial, obese women are more prone to anovulation and having abnormal uterine bleeding, endometrial hyperplasia, gynecological cancers, infertility, miscarriage, and antenatal and neonatal complications [9-11]. Obese women also exhibit impairments in ovarian, follicular, and oocyte development, fertilization, and embryo development and implantation $[12,13]$.

The quality and quantity of the oocyte reservoir has been described as ovarian reserve. This refers to an indirect index of a female's reproductive capacity [14]. Like all screening tests, ovarian reserve tests are aimed at identifying individuals at risk for diminished ovarian reserve. Over the past two decades, several methods have been described to predict the ovarian reserve. Anti-Mullerian hormone $(\mathrm{AMH})$ is a member of the transforming growth factor $\beta$ superfamily of glycoproteins and is produced by the granulosa cells of the preantral and small antral follicles [15]. AMH reflects the quantity of growing follicles and the ovarian follicular pool [16]. Although basal follicle-stimulating hormone (FSH) levels are the most commonly used ovarian reserve test, antral follicle counts and $\mathrm{AMH}$ levels are promising predictors with significant potential advantages [17]. For now, $\mathrm{AMH}$ is considered as a reliable indicator of declining ovarian function since $\mathrm{AMH}$ exhibits minimal inter- and intra-cycle variations [18].

There are numerous publications stating that the obesity leads to infertity through various pathways, including impaired follicular development, quantitative and qualitative development of the oocyte $[12,19]$. In the existing literature, conflicting results from studies examining the relationship between obesity and ovarian reserve have been reported. While some studies have demonstrated a significant reverse correlation [20,21], others have demonstrated no relationship between ovarian reserve markers and obesity [22-24].

Therefore, we aimed to investigate whether obesity adversely affects serum concentrations of ovarian reserve markers in women with different ovarian reserve status in the present study.

\section{Material and Methods}

\section{Study population}

A total of 485 infertile women who had attended the Reproductive Endocrinology Department at Hitit University Hospital between February and December 2015 were included in this prospective cross-sectional study. The study was performed in accordance with the Declaration of Helsinki 2013 Brazil version and was approved by the local ethics board of Ankara Numune Education and Research Hospital (20796219-724.087). All participants gave their written informed consent prior to the beginning of the study. The comprehensive personal and family histories were obtained from all participants. The participants who had a history of pelvic surgery, endometriosis, tubo-ovarian masses, cardiovascular, hepatic, renal and respiratory diseases, diabetes mellitus, malignancies, chemotherapy, or radiotherapy were excluded from the study. The current use of hormones or drugs that may have affected ovarian functions, smoking, pregnancy and lactation, an FSH level $>15 \mathrm{IU} / \mathrm{L}$, hyperprolactinemia, and an age $\geq 45$ years were also considered exclusion criteria. In total, 402 participants who met the inclusion criteria were included into the study.

\section{Study design}

A physical examination and measurements for weight, height, and WC were performed on all participants. BMI was calculated by dividing the weight in kilograms by the height in square me- 
ters. WC values were measured at the level of the iliac processes and umbilicus with the same scale to evaluate abdominal obesity. The transvaginal ultrasound examinations were also performed during the early follicular phase of the menstrual cycle (day 2 to 4) by means of a transvaginal 7.5 MHz probe (Toshiba Xario 100, Toshiba Medical Systems Co., Nasu, Japan) by the same clinician. The total antral follicle count (AFC) was the sum of the small follicles (2-10 $\mathrm{mm}$ in diameter) in each ovary.

All participants were assigned to three groups according to BMI (<25 kg/m²: normal group, $n=198 ; 25.0-29.9 \mathrm{~kg} / \mathrm{m}^{2}$ : overweight group, $n=126$; and $\geq 30 \mathrm{~kg} / \mathrm{m}^{2}$ : obese group, $n=78$ ). The women were also divided into two groups according to WC (<80 cm: normal group, $\mathrm{n}=103$; and $\geq 80 \mathrm{~cm}$ : obese group, $n=299$ ). Additionally, all participants were categorized into three types of ovarian reserve patterns. These patterns included the normal ovarian group $(n=146)$, which included women with an adequate reserve pattern (women with $\geq 7$ baseline AFC), the high ovarian group $(n=112)$ including women with a high reserve pattern according to the Rotterdam Consensus on Diagnostic Criteria for polycystic ovarian syndrome (PCOS) [25], and the poor ovarian group ( $n=144)$ that included women with a diminished reserve pattern (women with $<7$ baseline AFC), based on a committee opinion concerning ovarian reserve by the American College of Obstetricians and Gynecologists [26]. The comparisons of all data in all ovarian reserve groups were then drawn.

\section{Data collection and assays}

The blood samples were obtained from the antecubital vein after an overnight fast between 8:00 a.m. and 10:00 a.m. in the early follicular phase on day 2 or 3 . The blood samples were collected into $5 \mathrm{~mL}$ serum separator tubes (BD Vacutainer, Becton Dickinson, New Jersey, USA). The samples were allowed to clot completely at room temperature and were then centrifuged at $1500 \mathrm{~g}$ for $4 \mathrm{~min}$ within $30 \mathrm{~min}$. Serums were analyzed daily for es- tradiol (E2) and FSH with an electrochemiluminescence immunoassay (ECLIA) method using an autoanalyzer (Cobas 6000, E 601 Roche Diagnostics, GmbH, Mannheim, Germany). To obtain minimal fluctuations in the samples, the serum for $\mathrm{AMH}$ measurements were frozen at $-20^{\circ} \mathrm{C}$ within 2 hours for a maximum of 7 days and then analyzed. All analyses of $\mathrm{AMH}$ samples were also performed on a weekly basis by the ECLIA method using an autoanalyzer (Cobas 6000, E 601 Roche Diagnostics, GmbH, Mannheim, Germany).

\section{Statistical analyses}

All analyses were performed using SPSS (Statistical Packages for The Social Sciences) software version 21 (SPSS Inc., Chicago, IL, USA). For the categorical variables, chi-square tests were used. The continuous variables were first evaluated for normality of statistical distribution by Shapiro-Wilk tests. As the continuous variables were not normally distributed, non-parametric methods (Mann-Whitney $U$ tests) were used to perform statistical analyses. The descriptive statistics were expressed as a median (minimummaximum) and number (percentage \%). The Spearman correlation tests were used to determine the correlations of continuous variables. A p value of $<0.05$ and a confidence interval of $95 \%$ were considered as statistically significant.

\section{Results}

\section{Baseline demographic and biochemical characteristics}

The demographic and biochemical characteristics of the study population regarding the aspects of ovarian reserve groups are presented in $>$ Table 1 . The comparisons of the mean ages in all ovarian reserve groups demonstrated a statistically significant difference $(p<0.001)$. The median age was 29 years $(18-34)$ for the normal reserve group, 27.5 years (18-34) for the high reserve

- Table 1 The demographic and biochemical charecteristics of the study population.

\begin{tabular}{|c|c|c|c|c|}
\hline & $\begin{array}{l}\text { Normal ovarian reserve group } \\
(n=146)\end{array}$ & $\begin{array}{l}\text { High ovarian reserve group } \\
(n=112)\end{array}$ & $\begin{array}{l}\text { Poor ovarian reserve group } \\
(n=144)\end{array}$ & $\mathbf{p}$ \\
\hline Age (years) & $29(18-34)$ & $27.5(18-34)$ & $36(20-45)$ & $0.000^{*}$ \\
\hline \multicolumn{5}{|l|}{$\operatorname{BMI}\left(\mathrm{kg} / \mathrm{m}^{2}\right)$} \\
\hline . $<25.0(n=198)$ & $77(38.9 \%)$ & $55(27.8 \%)$ & $66(33.3 \%)$ & \multirow[t]{3}{*}{0.813} \\
\hline - $25.0-29.9(n=126)$ & 44 (34.9\%) & 35 (27.8\%) & $47(37.3 \%)$ & \\
\hline$=\geq 30.0(n=78)$ & $25(32.1 \%)$ & $22(28.2 \%)$ & $31(39.7 \%)$ & \\
\hline \multicolumn{5}{|l|}{$W C(\mathrm{~cm})$} \\
\hline - $<80(n=103)$ & $37(43.1 \%)$ & $29(36.1 \%)$ & $37(20.8 \%)$ & \multirow[t]{2}{*}{0.065} \\
\hline - $\geq 80$ ( $n=299)$ & $109(31.6 \%)$ & $83(30.6) \%$ & $107(37.8 \%)$ & \\
\hline AMH (ng/dL) & $2.3(0.1-11.3)$ & $5.4(1.6-20.0)$ & $1.2(0.1-10.7)$ & $0.000^{*}$ \\
\hline E2 (pg/mL) & $44.0(3.0-263.0)$ & $37.0(5-167.1)$ & $46.0(5.0-347.0)$ & $0.002^{*}$ \\
\hline FSH (IU/L) & $7.0(0.1-13.8)$ & $6.0(3.3-9.9)$ & $7.6(0.2-15.0)$ & $0.000^{*}$ \\
\hline
\end{tabular}




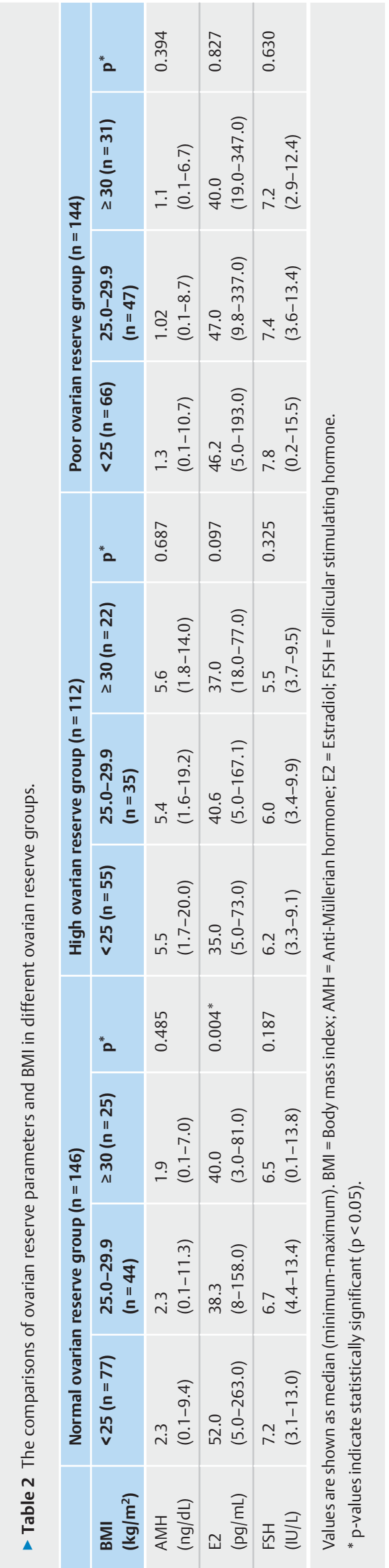

group, and 36 years (20-45) for the poor reserve group $(p<0.001)$. There were no significant differences in BMI and WC between the three ovarian reserve groups $(p=0.813$ and $p=0.065$, respectively). As expected, significant differences between all ovarian reserve groups with regard to $\mathrm{AMH}, \mathrm{E} 2$, and FSH levels were detected. The median $\mathrm{AMH}$ values of the normal, high, and poor ovarian groups were $2.3(0.1-11.3) \mathrm{ng} / \mathrm{dL}, 5.4$ $(1.6-20.0) \mathrm{ng} / \mathrm{dL}$, and $1.2(0.1-10.7) \mathrm{ng} / \mathrm{dL}$ respectively, $(p<0.001)$. Thus, the women with poor ovarian reserve had lower $\mathrm{AMH}$ concentrations. The median E2 values of the normal, high, and poor ovarian groups were $44.0(3.0-263.0) \mathrm{pg} / \mathrm{mL}, 37.0$ $(5.0-167.1) \mathrm{pg} / \mathrm{mL}$, and $46.0(5.0-347) \mathrm{pg} / \mathrm{mL}(\mathrm{p}<0.001)$, respectively. The normal, high, and poor ovarian groups also had statistically different median FSH levels with values of 7.0 (0.113.8) IU/L, 6.0 (3.3-9.9) IU/L, and 7.6 (0.2-15.5) IU/L respectively, $(p<0.001)$.

\section{Relationship of ovarian reserve parameters to $\mathrm{BMI}$ subgroups}

The comparisons of ovarian reserve parameters $(\mathrm{AMH}, \mathrm{FSH}$, and E2) and BMI subgroups are shown in > Table 2. All participants $(n=402)$ were grouped according to ovarian reserve status: normal $(n=146)$, high ( $n=112)$, and poor $(n=144)$ reserve groups. The mean serum AMH and FSH concentrations were statistically similar in all ovarian reserve groups and their BMI subgroups ( $p>0.05$, for all). By comparison of the mean E2 level, a significant difference was detected in the normal ovarian reserve group $(p=0.004)$. In this group, the women of normal weight $(\mathrm{BMI}<25)$ had the highest E2 $(52.0 \mathrm{pg} / \mathrm{mL})$ level. However, the high and poor ovarian reserve groups did not possessed any significant difference ( $p>0.05$, for all).

\section{Relationship of ovarian reserve parameters to WC subgroups}

The ovarian reserve parameters of study population were compared according to their WC subgroups, as demonstrated in $\triangleright$ Table 3. Although the mean FSH levels of normal ovarian reserve group were $7.2 \mathrm{IU} / \mathrm{L}$ and $6.7 \mathrm{IU} / \mathrm{L}$ respectively, no statistical significance was found $(p=0.177)$. On the contrary to $E 2$ comparisons in the normal ovarian BMI subgroups, the mean E2 levels in all ovarian reserve groups and WC subgroups were statistically similar ( $p>0.05$, for all). We also demonstrated that the mean AMH levels were not statistically different from each other in the three ovarian reserve groups ( $p>0.05$, for all).

\section{Discussion}

The overall aim of this study was to investigate whether obesity has an impact on the measures of ovarian reserve. Specifically, we conducted a comprehensive evaluation of this impact by assigning participants to three ovarian reserve groups. We hypothesized that obesity and body size would influence ovarian reserve markers. However, our findings did not support the notion that ovarian reserve is impaired in obese women.

In an earlier study, higher BMI levels were associated with lower inhibin B levels in premenopausal women, while the opposite results were observed in postmenopausal women [15]. A cross-sec- 
- Table 3 The comparisons of ovarian reserve parameters and WC in different ovarian reserve groups.

\begin{tabular}{|c|c|c|c|c|c|c|c|c|c|}
\hline \multirow[b]{2}{*}{$\begin{array}{l}\text { WC } \\
(\mathrm{cm})\end{array}$} & \multicolumn{3}{|c|}{ Normal ovarian reserve group $(n=146)$} & \multicolumn{3}{|c|}{ High ovarian reserve group $(n=112)$} & \multicolumn{3}{|c|}{ Poor ovarian reserve group $(n=144$ ) } \\
\hline & $<80(n=37)$ & $\begin{array}{l}\geq 80 \\
(n=109)\end{array}$ & $\mathbf{p}^{*}$ & $\begin{array}{l}<80 \\
(n=29)\end{array}$ & $\begin{array}{l}\geq 80 \\
(n=83)\end{array}$ & $\mathbf{p}^{*}$ & $\begin{array}{l}<80 \\
(n=37)\end{array}$ & $\begin{array}{l}\geq 80 \\
(n=107)\end{array}$ & $\mathbf{p}^{*}$ \\
\hline $\begin{array}{l}\text { AMH } \\
\text { (ng/dL) }\end{array}$ & $\begin{array}{l}2.3 \\
(0.4-9.2)\end{array}$ & $\begin{array}{l}2.3 \\
(0.1-9.4)\end{array}$ & 0.775 & $\begin{array}{l}5.0 \\
(1.6-19.2)\end{array}$ & $\begin{array}{l}5.5 \\
(1.8-20.0)\end{array}$ & 0.132 & $\begin{array}{l}0.8 \\
(0.1-4.3)\end{array}$ & $\begin{array}{l}1.2 \\
(0.1-10.7)\end{array}$ & 0.529 \\
\hline $\begin{array}{l}\mathrm{E2} \\
(\mathrm{pg} / \mathrm{mL})\end{array}$ & $\begin{array}{l}41.3 \\
(11.0-230.0)\end{array}$ & $\begin{array}{l}43.0 \\
(3.0-263.0)\end{array}$ & 0.898 & $\begin{array}{l}35.4 \\
(15.0-65.0)\end{array}$ & $\begin{array}{l}37.5 \\
(5.0-167.1)\end{array}$ & 0.692 & $\begin{array}{l}46.0 \\
(27.0-193)\end{array}$ & $\begin{array}{l}46.7 \\
(9.8-123.0)\end{array}$ & 0.963 \\
\hline $\begin{array}{l}\mathrm{FSH} \\
(\mathrm{IU} / \mathrm{L})\end{array}$ & $\begin{array}{l}7.2 \\
(4.7-12.6)\end{array}$ & $\begin{array}{l}6.7 \\
(0.14-13.4)\end{array}$ & 0.177 & $\begin{array}{l}6.3 \\
(3.4-8.7)\end{array}$ & $\begin{array}{l}6.0 \\
(3.3-9.9)\end{array}$ & 0.880 & $\begin{array}{l}8.3 \\
(4.7-12.6)\end{array}$ & $\begin{array}{l}7.2 \\
(2.1-15.5)\end{array}$ & 0.178 \\
\hline
\end{tabular}

tional study by Su et al. explored the association between obesity and serum and ultrasound measures of ovarian reserve in women of late reproductive age. This group reported that $\mathrm{AMH}$ was lower in obese women, while antral follicle count did not differ in accordance with body size [27].

De Pergola et al. proposed that overweight and fertile women with obesity have lower FSH, LH, inhibin B, and E2 concentrations. They concluded that a possible inhibitory effect of obesity on gonadotropins and E2 production may be one of the elucidative mechanisms [28]. Other authors have also reported similar results. Freeman et al. noted a negative correlation between BMI and $\mathrm{AMH}$ in later reproductive-age women. They found that obese women had $65 \%$ lower AMH levels compared to women of normal weight [20]. Steiner et al. also reported that obese women had 34\% lower levels of AMH [29]. However, other authors have suggested that lower AMH levels in late reproductive-age obese women result from physiological processes other than decreased ovarian reserve $[20,27]$.

In contrast to the studies in which ovarian reserve has been negatively affected by high BMI levels, several studies have demonstrated that serum and ovarian markers of diminished ovarian reserve (DOR) did not exhibit consistent changes with body size [30 - 32]. In parallel with our study, some authors have reported no significant relationships between circulating $\mathrm{AMH}$ levels and obesity. Nardo et al. and Halawaty et al. did not detect any differences in FSH, AMH, AFC, and ovarian volume [22,33]. Furthermore, in a prospective case-controlled study, Shaw et al. found no correlation between AMH levels and increased BMI levels in 135 Caucasian premenopausal women, $16 \%$ of whom were obese women younger than 45 years of age [34]. In a cross-sectional study from Turkey, Sahmay et al. also evaluated 259 premenopausal women, $14 \%$ of whom were were obese women under 45 years of age. They concluded there was no significant association between AMH and obesity [35].

Moy et al. sought to determine whether the association between obesity and $\mathrm{AMH}$ would be dependent on racial factors. They performed a study that included 350 women, 99 of whom were African-Americans, 59 were Caucasians, 58 were Hispanics, and 34 were Asians. They concluded that obesity is inversely correlated with $\mathrm{AMH}$ in Caucasian women, but not in other racial groups. Interestingly, when women with DOR were examined independently, an association between BMI and AMH was reported. However, this same study demonstrated no association between $\mathrm{BMI}$ and $\mathrm{AMH}$ in women with normal ovarian reserve [36]. Moreover, all ovarian reserve patterns, including normal, high, and poor patterns, were not affected by increased BMI and body size. However, in our study there was no such relationship between obesity and AMH in 402 Caucasian premenopausal women. Moreover, we did not demonstrate any association between BMI and $\mathrm{AMH}$ in women with normal, high, and poor reserves.

In contrast to the present study, a very recent systematic review and meta-analysis conducted by Moslehi et al. reported that ovarian reserve markers of AMH and FSH were significantly lower in obese than in non-obese women [37].

Interestingly, another finding is that the mean E2 level was higher only in the women of normal weight of the normal ovarian reserve group. In a study, it was demonstrated that higher serum levels of leptin in obese women correlate with higher levels of leptin in the follicular fluid [38]. In vitro studies have shown that leptin affects steroidogenic pathways in granulose cells, decreasing estrogen and progesterone production in a dose dependent manner $[39,40]$. This mechanism for the adipokines might be the explanation of the highest E2 level in the group of women of normal weight. Nevertheless, it is essential to accomplish further studies in order to reveal the causal relationship between E2 and BMI subgroups in other ovarian reserve groups.

The main strength of our study is the large sample size compared to many prior studies evaluating the effects of obesity on ovarian reserve markers. Another strength is that we included WC as another marker of abdominal obesity. In addition to these strengths, three groups of ovarian reserve (normal, high, and poor) were evaluated to determine the effect of obesity on different levels of ovarian reserve. A potential limitation of this study is that the study population primarily consisted of women who were being treated for infertility, and we did not have any fecundity data for the study group.

In summary, our findings do not support any effect of obesity on ovarian reserve markers. In other words, the parameters of ovarian reserve do not seem to be affected by increased BMI and WC. Nevertheless, the decrease in fecundity in infertile obese 
women may arise from other multiple factors including folliculogenesis and endometrial receptivity. Because there is no relationship between obesity and $\mathrm{AMH}, \mathrm{AMH}$ may be considered as a reliable marker of ovarian reserve. The etiologies for diminished ovarian reserve other than obesity also may be necessary to investigate. Further clinical and basic research studies are needed to elucidate the role of obesity on ovarian reserve and reproductive functions.

\section{Funding}

This research was supported by the Scientific Research Unit of Hitit University, Corum, Turkey (TIP19001.14.005).

\section{Conflict of Interest}

The authors declare that they have no conflict of interest.

\section{References}

[1] Ravussin E, Swinburn BA. Pathophysiology of obesity. Lancet 1992; 340: 404-408

[2] World Health Organization. Preventing and managing the global epidemic. Report of the World Health Organization on obesity. Geneva: World Health Organization; 1997

[3] World Health Organization. Obesity: preventing and managing the global epidemic. Report of a WHO consultation. World Health Organization Technical Report Series 894. Geneva: World Health Organization: 2000

[4] Onat A, Avci GS, Barlan MM et al. Measures of abdominal obesity assessed for visceral adiposity and relation to coronary risk. Int J Obes Relat Metab Disord 2004; 28: 1018-1025

[5] Sonmez A, Bayram F, Barcin C et al. Waist Circumference Cutoff Points to Predict Obesity, Metabolic Syndrome, and Cardiovascular Risk in Turkish Adults. Int J Endocrinol 2013; 2013: 767202

[6] Haslam DW, James WP. Obesity. Lancet 2005; 366: 1197-1209

[7] Gundogan K, Bayram F, Gedik V et al. Metabolic syndrome prevalence according to ATP III and IDF criteria and related factors in Turkish adults. Arch Med Sci 2013; 9: 243-253

[8] Satman I, Omer B, Tutuncu Y et al. TURDEP-II Study Group. Twelve-year trends in the prevalence and risk factors of diabetes and prediabetes in Turkish adults. Eur J Epidemiol 2013; 28: 169-180

[9] Epplein M, Reed SD, Voigt LF et al. Risk of complex and atypical endometrial hyperplasia in relation to anthropometric measures and reproductive history. Am J Epidemiol 2008; 168: 563-570

[10] Boots C, Stephenson MD. Does obesity increase the risk of miscarriage in spontaneous conception: a systematic review. Semin Reprod Med 2011; 29: $507-513$

[11] Marshall NE, Spong CY. Obesity, pregnancy complications, and birth outcomes. Semin Reprod Med 2012; 30: 465-471

[12] Jungheim ES, Travieso JL, Hopeman MM. Weighing the impact of obesity on female reproductive function and fertility. Nutr Rev 2013; 71 (Suppl. 1): S3-S8

[13] Rittenberg V, Seshadri S, Sunkara SK et al. Effect of body mass index on IVF treatment outcome: an updated systematic review and meta-analysis. Reprod Biomed Online 2011; 23: 421-439

[14] Gupta S, Sharma D, Surti N et al. Ovarian reserve testing: systematic review of the literature. Arch Med Sci 2009; 5: S143-S150

[15] Durlinger AL, Visser JA, Themmen AP. Regulation of ovarian function: the role of anti-müllerian hormone. Reproduction 2002; 124: 601-609
[16] Visser JA, de Jong FH, Laven JS et al. Anti-Müllerian hormone: a new marker for ovarian function. Reproduction 2006; 131: 1-9

[17] Fritz MA, Speroff L. Female Infertility. In: Fritz MA, Speroff L, eds. Clinical gynecologic Endocrinology and Infertility. 8th ed. Philadelphia: Lippincott Williams \& Wilkins; 2011: 1137-1190

[18] Seifer DB, Maclaughlin DT. Mullerian inhibiting substance is an ovarian growth factor of emerging clinical significance. Fertil Steril 2007; 88 : 539-546

[19] Fedorcsák P, Dale P, Storeng R et al. Impact of overweight and underweight on assisted reproduction. Hum Reprod 2004; 11: 2523-2528

[20] Freeman EW, Gracia CR, Sammel MD et al. Association of anti-mullerian hormone levels with obesity in late reproductive-age women. Fertil Steril 2007; 87: 101-106

[21] Georgopoulos NA, Saltamavros AD, Decavalas G. Serum AMH, FSH, and LH levels in PCOS. Fertil Steril 2010; 93: e13

[22] Nardo LG, Christodoulou D, Gould D et al. Anti-mullerian hormone levels and antral follicle count in women enrolled in in vitro fertilization cycles: relationship to lifestyle factors, chronological age and reproductive history. Gynecol Endocrinol 2007; 23: 486-493

[23] Wunder DM, Bersinger NA, Yared M et al. Statistically significant changes of antimüllerian hormone and inhibin levels during the physiologic menstrual cycle in reproductive age women. Fertil Steril 2008; 89: 927-933

[24] Park AS, Lawson MA, Chuan SS et al. Serum anti-müllerian hormone concentrations are elevated in oligomenorrheic girls without evidence of hyperandrogenism. J Clin Endocrinol Metab 2010; 95: 1786-1792

[25] The Rotterdam ESHRE and ASRM-sponsored PCOS consensus workshop group. Revised 2003 consensus on diagnostic criteria and long-term health risks related to polycystic ovary syndrome. Fertil Steril 2004; 81: 19-25

[26] Committee on Gynecologic Practice. Committee opinion No. 618: Ovarian reserve testing. Obstet Gynecol 2015; 125: 268-273

[27] Su HI, Sammel MD, Freeman EW et al. Body size affects measures of ovarian reserve in late reproductive age women. Menopause 2008; 15 : 857-861

[28] De Pergola G, Maldera S, Tartagni M et al. Inhibitory effect of obesity on gonadotropin, estradiol, and inhibin B Levels in fertile women. Obesity (Silver Spring) 2006; 14: 1954-1960

[29] Steiner AZ, Stanczyk FZ, Patel S et al. Antimullerian hormone and obesity: insights in oral contraceptive users. Contraception 2010; 81: 245248

[30] Gracia CR, Freeman EW, Sammel MD et al. The relationship between obesity and race on inhibin $B$ during the menopause transition. Menopause 2005; 12: 559-566

[31] Sowers $\mathrm{M}$, Zheng $\mathrm{H}$, Tomey $\mathrm{K}$ et al. Changes in body composition in women over six years at midlife: ovarian and chronological aging. J Clin Endocrinol Metab 2007; 92: 895-901

[32] Freeman EW, Sammel MD, Gracia CR et al. Follicular phase hormone levels and menstrual bleeding status in the approach to menopause. Fertil Steril 2005; 83: 383-392

[33] Halawaty S, El Kattan E, Azab H et al. Effect of obesity on parameters of ovarian reserve in premenopausal women. J Obstet Gynaecol Can 2010; 32: 687-690

[34] Shaw CM, Stanczyk FZ, Egleston BL et al. Serum antimüllerian hormone in healthy premenopausal women. Fertil Steril 2011; 95: 2718-2721

[35] Sahmay S, Usta T, Erel CT et al. Is there any correlation between amh and obesity in premenopausal women? Arch Gynecol Obstet 2012; 286: 661-665

[36] Moy V, Jindal S, Lieman $\mathrm{H}$ et al. Obesity adversely affects serum antimüllerian hormone (AMH) levels in Caucasian women. J Assist Reprod Genet 2015; 32: 1305-1311 
[37] Moslehi N, Shab-Bidar S, Ramezani Tehrani F et al. Is ovarian reserve associated with body mass index and obesity in reproductive aged women? A meta-analysis. Menopause 2018. doi:10.1097/GME.00000000000 01116

[38] Hill M], Uyehara CF, Hashiro GM et al. The utility of serum leptinand follicular fluid leptin, estradiol, and progesterone levels during an in vitro fertilization cycle. J Assist Reprod Genet 2007; 24: 183-188
[39] Lin Q, Poon SL, Chen J et al. Leptin interferes with 30,50-cyclic adenosine monophosphate (CAMP) signaling to inhibit steroidogenesis in human granulosa cells. Reprod Biol Endocrinol 2009; 7: 115

[40] Brannian JD, Zhao Y, McElroy M. Leptin inhibits gonadotrophinstimulated granulosa cell progesterone production by antagonizing insulin action. Hum Reprod 1999; 14: 1445-1448 